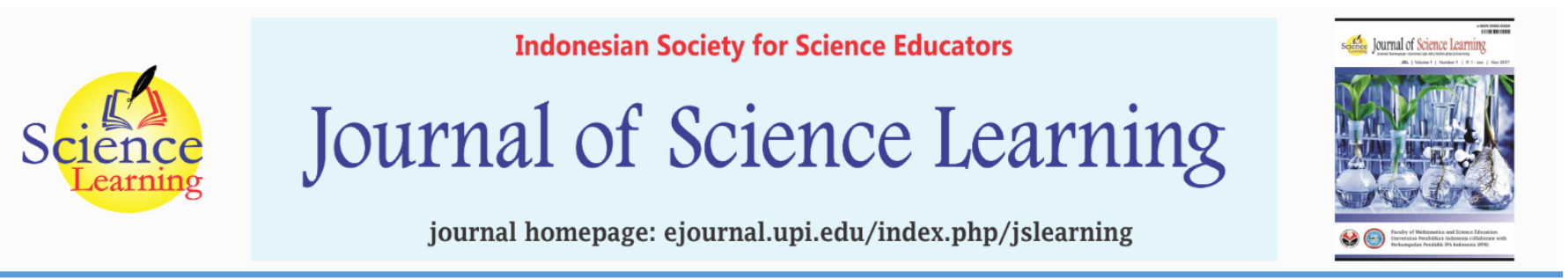

\title{
Secondary School Students' Knowledge and Views on Laboratory Safety
}

\author{
Belkız Caymaz ${ }^{1 *}$ \\ ${ }^{1}$ Ministry of National Education, Turkey \\ *Corresponding Author caymazbelkiz@gmail.com
}

\begin{abstract}
Laboratory studies are very important for science education but also involve various risks. It is possible to minimize these risks by providing a safe working environment. This study aims to determine the knowledge and views of secondary school students on laboratory safety and to identify their deficiencies in this regard. The survey method was used in the study. The study sample consists of 136 students from 6th, 7th, and 8th-grade students of a public secondary school in Kastamonu Province, Turkey. An open-ended questionnaire was used to determine the students' knowledge and views on the subject, and the data obtained were analyzed by the content analysis method. As a result of the study, it was seen that although secondary school students have some general information about laboratory safety, they have deficiencies in terms of most of the information. It was determined that students do not know most of the behaviors that must/must not be made in the laboratory, and they are not aware of some of the safety symbols in the science textbooks. In addition, most of the students stated that they don't feel competent about laboratory safety and need training on this subject.
\end{abstract}

Keywords Science Lesson, Laboratory Safety, Secondary School Students

\section{INTRODUCTION}

Laboratory studies are an integral part of science education and provide students with various opportunities to learn by doing and experiencing (Hamurcu, 1998; Yazıc1 \& Özmen, 2015). Well-designed laboratory studies encourage students to question, think scientifically and interpret the events around them (Aydoğdu, 2018). It also contributes to developing students' psycho-motor skills and communication skills (Hofstein \& Lunetta, 2004). Despite its various benefits, the teachers do not want to do laboratory studies for various reasons (Hackling, Goodrum \& Rennie, 2001; Yazıc1 \& Özmen, 2015). Insufficient course time (Hackling, Goodrum \& Rennie, 2001; Hodson, 1990; Yazıc1 \& Özmen, 2015), crowded classes (Aydoğdu, 2018; Uluçınar, Cansaran \& Karaca, 2004), labs being inadequate in terms of equipment (Hofstein \& Lunetta, 2004; Nakiboğlu \& Sarıkaya, 1999; Yazıc1 \& Özmen, 2015) are among the factors that hinder laboratory studies. Böyük, Demir \& Erol (2010) found in their study that secondary school science teachers did not know the laboratory materials sufficiently, could not use them and did not have enough knowledge of maintenance and repair of these materials. Teachers feel insufficient in terms of knowledge and skills for laboratory use and have difficulty providing classroom management. For this reason, they prefer to teach science in the classroom, even if the physical conditions in the laboratory are suitable. Another reason teachers avoid using the laboratory is the insecurity they feel about laboratory safety (Nakiboğlu \& Sarıkaya, 1999; Yazıc1 \& Özmen, 2015). Laboratory studies are required for effective science education; however, they must be planned very carefully due to the dangers they may contain. At this point, ensuring laboratory safety is the essential condition.

Laboratory safety is the process of taking precautions against accidents and dangers that may occur during laboratory studies, determining the problems that may occur in the laboratory, and solving the problems with scientific methods (Bayraktar, Erten \& Aydoğdu, 2006). In addition, laboratory safety can be defined as following specific laboratory rules to protect people and the environment during laboratory studies and utilize laboratory equipment in the most appropriate way (Deniz \& Ercan-Kalkan, 2013). Laboratory accidents are inevitable when safety precautions are not observed. These accidents may result in simple injuries as well as very serious situations such as loss of life. The main causes of accidents include the incorrect design of laboratories, improper storage of materials and equipment, the absence or non-use

Received: 27 December 2020

Revised: 03 March 2021

Published: 03 July 2021 
of protective equipment for safety. In addition, crowded classes, unwanted student behaviors, carelessness, tiredness, teachers and students not having enough information about the properties of chemicals are among the other reasons (Aydoğdu \& Yardımc1, 2013; Aydoğdu \& Pekbay, 2016; Nwele, 2013; West, Westerlund, Stephenson, Nelson \& Nyland, 2003). There have been many accidents due to these reasons. For example, methanol caught fire during the experiment, and one student had severe burns (Gerlovich, Parsa \& Jordan, 2004). A student who did not listen to the teacher's warnings added water over the acid in another accident. As a result of the laboratory explosion, both the careless student and his partner were injured (Hill $\&$ Finster, 2010). These accidents show that unconscious and careless work can lead to many dangerous situations.

Both teachers and students have significant responsibilities to carry out laboratory studies safely. According to America's Lab Report (Singer, Hilton \& Schweingruber, 2006), teachers' responsibilities are: (1) the duty of teaching (the teacher must predetermine possible risks, inform the students in advance of possible dangers, teach the laboratory rules), (2) the duty of supervision (the teacher must constantly watch the students, not ignore those who exhibit wrong behavior, increase supervision in more dangerous studies), (3) the duty of maintenance (the teacher must never use a damaged material, prepare a written report for the maintenance and repair of the materials, act following the procedures for regular checks of the safety equipment). Eliminating the conditions that can cause injuries and accidents in the laboratory is one of the teacher's primary duties. However, students who will work in the laboratory should not forget that they are responsible for their safety and their people. Students should get information about the possible risks of the experiment in advance, follow and apply the safety instructions, listen to the warnings of the teacher carefully, learn what to do in case of an emergency, and inform the teacher about possible dangerous situations (Hasenekoğlu, 2003; Topsakal, 2006).

Most accidents are caused by human errors (Canel, 2002; Kerimak-Öner, 2020). For this reason, both teachers and students should have the necessary knowledge and skills to ensure laboratory safety. The most important thing to do is to identify the deficiencies of teachers and students in laboratory safety and provide the training they need. Aydoğdu \& Yardimci (2013) analyzed the news about laboratory accidents in local and national newspapers. As a result of the examination, it was determined that there were accidents such as test tube explosion, chemical spreading, gas release, etc. These accidents' leading causes include having inadequate/incorrect information about chemicals, carelessness, and unauthorized use of experimental materials by students. When the studies on laboratory safety were examined in the literature, it was seen that most of the studies were carried out with teachers and teacher candidates. In Demir's (2016) study, the "Laboratory Safety Knowledge Test" was applied to 74 science teachers, and it was observed that very few of them were successful in the test. Muhammad (2017) conducted a study that measured laboratory-related skills of science teachers in Nigeria, such as laboratory safety, using materials, experimenting, first aid. As a result of the study, it was reported that teachers have deficiencies in laboratory safety. Gudyanga (2020) researched the levels of chemical laboratory safety (CLS) awareness of physical sciences teachers. Teacher CLS awareness was generally suboptimal, especially concerning awareness of safe chemical storage and waste disposal and emergency laboratory safety procedures. The teacher candidates' knowledge and views on laboratory safety were investigated (Aydın, Diken, Yel \& Yılmaz, 2011; Kırbaşlar, Özsoy-Güneş \& Derelioğlu, 2010). It was reported that teacher candidates have general knowledge about laboratory safety, but they had deficiencies and did not sufficiently know the laboratory safety symbols. In the studies conducted by Anilan (2010), Gökmen \& Atmaca (2019), it was determined that the teacher candidates' level of awareness about safety symbols was low. The state of the secondary schools having laboratory safety equipment (Emendu, 2007; Nwele, 2013) was also investigated. The results showed that the laboratory conditions were not suitable for safety and the safety equipment was insufficient. Gerlovich, Parsa \& Jordan (2004) found that most teachers were not sufficiently aware of their legal and professional responsibilities regarding laboratory safety, and they prepared a safety education program.

The number of studies conducted with students on laboratory safety is very limited. In the study conducted by Yllmaz (2005), a test including laboratory safety and the dangers of chemical substances was applied to high school students. It was observed that the students had the basic knowledge required for laboratory studies, but their safety knowledge on chemical substances was insufficient. Alaimo, Langenhan, Tanner \& Ferrenberg (2010) prepared a training program on laboratory safety. Stating that the students were bored of reading the papers on which the safety rules were written, they trained them for a year in remarkable ways such as safety games, puzzles, cartoons, and videos. Ali et al. (2018) selected eight secondary schools to determine students' awareness of laboratory safety in Pahang, Malaysia. A Likert-type questionnaire with five components (work procedure, safety equipment, handling experiments, chemical waste management, emergency response plan) was applied to the students from schools located in urban and rural areas. This study indicates that the overall level of students' awareness on laboratory safety is at medium-high level, and this has shown that the existing measures in secondary school to enhance awareness of laboratory safety are adequate. It might help minimize the accidents that may occur if the students act consciously during the laboratory studies, obey 
the safety rules, and realize possible safety problems. When the studies were examined, there was no study investigating secondary school students' knowledge and views on laboratory safety. Due to the scarcity of studies on laboratory safety, it is aimed that this study will contribute to the field.

This study aims to determine the knowledge and views of secondary school students on laboratory safety and to identify their deficiencies in this regard. For this purpose, answers to the following questions were sought: (1) What is the knowledge of secondary school students about laboratory safety?. (2) What are the views of secondary school students on laboratory safety?

\section{METHOD}

This research was carried out using the survey method, which is one of the quantitative research methods. The survey method aims to describe an existing situation as it is, and the individual or object is tried to be defined as it is in its conditions (Karasar, 2004).

\subsection{Sampling}

The research was conducted with 6th, 7th, and 8thgrade students of a public secondary school in the fall semester of the 2019-2020 academic year in Kastamonu Province, Turkey. A total of 136 students, including 39 students from the 6th Grade, 54 students from the 7th Grade, and 43 students from the 8th Grade, voluntarily participated in the study. The criterion sampling method was used in determining the sample. It is the sampling method in which people, events, objects, or situations with predetermined qualities are selected (Yıldırım \& Şimşek, 2006). The school has two science teachers and a laboratory. Before the research, science teachers were interviewed, and information was obtained about their laboratory use. The most important criterion in choosing the school was that science teachers use the laboratory actively and alternately.

\subsection{Data Collection Tool}

The researcher developed an open-ended questionnaire to determine the students' knowledge and views on laboratory safety. First, a draft form consisting of eight questions was created. Similar studies in the literature were examined (Aydın, Diken, Yel \& Y1lmaz, 2011; 2011; Demir, 2016; Kırbaşlar, Özsoy-Güneş \& Derelioğlu, 2010), and these studies were used to form some questions. For example, Aydin, Diken, Yel \& Yilmaz (2011) asked the teacher candidates to write down the safety errors they saw in the picture. In this study, students were shown a picture and asked to write down the right and wrong behaviors they saw. The picture used by Aydın, Diken, Yel \& Yılmaz, 2011 (2011) and the picture used in this study were different. The draft form was submitted for expert opinion (two faculty members, three science teachers, and two Turkish teachers) to be examined in terms of language and content. Necessary corrections were made in line with expert opinions, and two questions were removed from the questionnaire. Then, five students selected from a different school were interviewed to check the questionnaire's comprehensibility. In line with the interviews, the students' expressions were not understood or perceived differently, and the questionnaire consisting of six questions was finalized.

The questionnaire consists of two parts (Appendix). In the first part, there are two questions for determining the students' knowledge: (1) The picture of students working in the laboratory was given. The correct and wrong behaviors of the students were asked. (2) 11 safety symbols were given, and they were asked what they mean. These are common symbols found in 6th, 7th, and 8th-grade science textbooks. In the second part, there are four questions for determining the views of the students. The students were asked: (1) do they have enough information about laboratory safety?, (2) what should be considered in terms of safety during laboratory studies, (3) what kind of problems may arise when safety precautions are not taken into consideration in laboratory studies. (4) what are their expectations from science teachers and school administrators regarding laboratory safety? The first and second parts of the questionnaire were applied on different days. One lesson hour (40 minutes) was given to students for both parts. There was a possibility that taking a long time to answer the questionnaire could cause students to get bored and carelessly answer the last questions. This possibility has been taken into consideration, and possible data loss has been tried to be prevented.

\subsection{Analysis of the Data}

Descriptive statistics such as frequency and percentage were used to analyze the first part and the first question in the second part of the questionnaire. Content analysis was used to analyze the $2 \mathrm{nd}, 3 \mathrm{rd}$, and 4 th questions in the second part. There are two types of approaches in content analysis, namely "inductive" and "deductive." If there is not enough information about the subject under study, then the inductive approach will go from specific to general (Hsieh \& Shannon, 2005). In this context, the inductive content analysis approach was used in this study. In content analysis, data are analyzed in four stages; (1) coding, (2) finding themes, (3) organizing codes and themes, (4) defining and interpreting the findings (Çepni, 2012). The data obtained were first coded, and themes were created. Then, themes and codes were tabulated, and the frequency and percentage value of each code were calculated.

The questionnaires collected in the study were given to a science educator working at the state university's education faculty. The science educator randomly and equally selected and analyzed questionnaires from each grade level $(25 \%)$. The codings made independently by the researcher and the science educator were compared. The reliability percentage was calculated with the formula suggested by Miles \& Huberman (1994). As a result of the 
calculation, a value of .80 and above indicates that the evaluation is reliable (Miles \& Huberman, 1994; Miles, Huberman \& Saldana, 2014). In this study, the agreement percentage between coders was found to be .94. This result shows that the evaluation made is reliable. Non-compliance points were reviewed together, and a common decision was reached.

\section{RESULT AND DISCUSSION}

In this section, the data obtained from the questionnaire were arranged and interpreted according to each subproblem. The data were analyzed both in general (all students) and separately for each grade level.

\subsection{Secondary School Students' Knowledge About Laboratory Safety}

In the first part of the questionnaire, two questions were asked to the students. In the first question, the students were asked what the right and wrong behaviors were in the picture's laboratory environment. The frequency and percentage values of the obtained findings are given in Table 1.

When Table 1 is examined, it is seen that the most determined right behaviors in the picture are "regularity of the materials on the shelf (46.3\%), a student wearing lab glasses $(38.2 \%)$ and a student wearing a lab coat (30.1\%)". The most determined wrong behaviors are "some students eating and drinking somethings (88.9\%), disorganized laboratory $(79.4 \%)$, spilling the liquid in the broken glass beaker to the floor $(56.6 \%)$ ". All right and wrong behaviors in the picture have been identified. However, the number of students varies according to the grade level. "The regularity of the materials on the shelf" is the most emphasized right behavior at each grade level (48.7\%57.4\%-30.2\%). "A student wearing lab glasses and wearing a lab coat" is the right behavior mainly detected by 7 th graders $(72.2 \%-44.4 \%)$. While the "the material cabine has fixed to the wall", which is very important in terms of laboratory safety, was determined as the right behavior by only two 6th grade students, it is noteworthy that no students detected this the 7th and 8th grades. Students identified 19 wrong behaviors in the picture. "Some students eating or drinking somethings" (97.4\%-90.7\%$79 \%$ ) and " disorganized laboratory" (84.6\%-81.4\%-72\%) are the most defined wrong behaviors at every grade level. Besides, "spilling the liquid in the broken glass beaker to the floor" (43.5\%-68.5\%-53.4\%) and "the microscope not unplugged" (43.5\%-38.8\%-58.1\%) was reported as wrong behaviors by most students. Very few students mentioned wrong behaviors such as not using protective equipment

Table 1 The right and wrong behaviors seen in the laboratory environment

\begin{tabular}{|c|c|c|c|c|c|c|c|c|c|}
\hline \multirow[t]{2}{*}{ Themes } & \multirow[t]{2}{*}{ Codes } & \multicolumn{2}{|c|}{ 6th Grade } & \multicolumn{2}{|c|}{ 7th Grade } & \multicolumn{2}{|c|}{ 8th Grade } & \multicolumn{2}{|c|}{ Total } \\
\hline & & $\mathrm{f}$ & $\%$ & $\mathrm{f}$ & $\%$ & $\mathrm{f}$ & $\%$ & $\mathrm{f}$ & $\%$ \\
\hline Right & Some chairs are in place & 4 & 10.2 & 8 & 14.8 & 12 & 27.9 & 24 & 17.6 \\
\hline \multirow[t]{3}{*}{ Behaviors } & Regularity of the materials on the shelf & 19 & 48.7 & 31 & 57.4 & 13 & 30.2 & 63 & 46.3 \\
\hline & A student sitting in place & 4 & 10.2 & - & - & 5 & 11.6 & 9 & 6.6 \\
\hline & A student wearing lab glasses & 3 & 7.6 & 39 & 72.2 & 10 & 23.2 & 52 & 38.2 \\
\hline Wrong & Some students eating or drinking somethings & 38 & 97.4 & 49 & 90.7 & 34 & 79 & 121 & 88.9 \\
\hline \multirow[t]{13}{*}{ Behaviors } & Spilling the liquid in the broken glass beaker to the floor & 17 & 43.5 & 37 & 68.5 & 23 & 53.4 & 77 & 56.6 \\
\hline & $\begin{array}{l}\text { Disorganized laboratory (bag and chair thrown on the } \\
\text { floor) }\end{array}$ & 33 & 84.6 & 44 & 81.4 & 31 & 72 & 108 & 79.4 \\
\hline & The microscope not unplugged & 17 & 43.5 & 21 & 38.8 & 25 & 58.1 & 63 & 46.3 \\
\hline & Lab coat not worn & - & - & 3 & 5.5 & 1 & 2.3 & 4 & 2.9 \\
\hline & Gloves not worn while doing the experiment & 2 & 5.1 & 8 & 14.8 & 10 & 23.2 & 20 & 14.7 \\
\hline & The lab is not clean & 4 & 10.2 & 5 & 9.2 & 9 & 20.9 & 18 & 13.2 \\
\hline & A student sniffs the gas he doesn't know & 6 & 15.3 & 1 & 1.8 & 2 & 4.6 & 9 & 6.6 \\
\hline & Most students walking around & 6 & 15.3 & 2 & 3.7 & 3 & 6.9 & 11 & 8.1 \\
\hline & Students touching materials they do not know & 2 & 5.1 & 7 & 12.9 & 12 & 27.9 & 21 & 15.4 \\
\hline & Damaging to materials/stuffs in the laboratory & 1 & 2.5 & 4 & 7.4 & 3 & 6.9 & 8 & 5.8 \\
\hline & Safety precautions not taken & 3 & 7.6 & 2 & 3.7 & 8 & 18.6 & 13 & 9.5 \\
\hline & The materials used has not removed in place & 1 & 2.5 & 1 & 1.8 & 2 & 4.6 & 4 & 2.9 \\
\hline & Glass beaker on the table is about to fall to the floor & 4 & 10.2 & - & - & 4 & 9.3 & 8 & 5.8 \\
\hline
\end{tabular}


(lab glasses, lab coat, gloves) and making experiments dangerously without teacher supervision.

Most of the students do not know precisely what is right and what is wrong during laboratory studies. This may be due to the teacher's attitude during laboratory studies. The teacher's warnings, the rules he/she cares about, the behaviors he/she pays attention to affect and shape the students' behavior. For example, if the teacher warns the students about the subject more often, their attention may be directed to that behavior. Similarly, if the teacher does not use protective equipment such as gloves or lab glasses in laboratory studies, it may cause students to perceive this behavior as a normal situation and not see it as a deficiency. Aydın, Diken, Yel \& Y1lmaz, 2011 (2011) asked prospective science and biology teachers to explain the safety errors they saw in the picture. Some errors were detected by most prospective teachers, while some errors were detected by a very small number of prospective teachers. In other studies in the literature, it was concluded that science teachers (Demir, 2016; Muhammad, 2017) and prospective teachers (Kırbaşlar, Özsoy-Güneş \& Derelioğlu, 2010) had insufficient knowledge about laboratory safety. Although the sample groups of these studies and the present study are different, their findings are similar.

In the second question, the meanings of some laboratory safety symbols were asked. The frequency and percentage values of the students who gave the right answer are given in Table 2.

In Table 2 , it is seen that the eye safety $(92.6 \%)$ symbol is the most known, while the symbols of plant safety $(22.7 \%)$ and animal safety $(22.1 \%)$ are the least known. It is also seen that most students know some safety symbols (eye safety, sharp and pointed objects, hand safety, chemical substance warning, hand cleaning warning, lab coat warning) at all grade levels. While most of the 7 th and 8th graders were known while the heat safety symbol was known, the rate of correct answers was found to be low in 6th graders. While nearly half of the 7 th graders $(51.8 \%)$ explained the plant safety symbol correctly, only one student $(2.5 \%)$ from the 6th Grade and two students from the 8th Grade (4.6\%) explained it correctly. Similarly, half of the 7th graders $(53.7 \%)$ answered the animal safety symbol correctly, only one of the 8 th graders $(2.3 \%)$ gave the correct answer. It is noteworthy that no student from the 6th Grade gave the right answer about the animal safety symbol. The most known and least known symbols differ by grade level. In the 6th Grade, the symbol of "hand safety" is the most known. The symbol of "animal safety" is unknown. In the 7th Grade, the symbol of "eye safety" is the most known, and the symbol of "plant safety" is the least known. In the 8th Grade, the symbol of "eye safety" is the most known, and the symbol of "animal safety" is the least known.

When the explanations of the students were examined, it was seen that the students made explanations according to the picture in the symbol. For example, the animal safety symbol has a mouse image representing the live animal. Most students thought this symbol was only about the mouse because of the picture and explained this direction. Similarly, the presence of a picture of glasses in the eye safety symbol may have facilitated the symbol's recognition. The study's findings show that the pictures on the symbols facilitate the recognition of the symbol but do not provide enough information for students. Similar findings have been reached in studies conducted on different samples in the literature. Aydin, Diken, Yel \& Y1lmaz, 2011 (2011) found that some safety symbols were known by most prospective teachers, while a small number knew some of them. In other studies, it was reported that prospective science teachers (Anilan, 2010), prospective classroom teachers (Gökmen \& Atmaca, 2019) and prospective biology teachers (Derman \& Çakmak, 2016) did not know the safety symbols. Artdej (2012) investigated Thai undergraduate students' scientific understanding of safety symbols. The findings indicated that most of the students experienced confusion in the meaning of chemical safety symbols, and they did not pay attention to safety symbols labeled on containers during experiments. Tepe and Tekbiylk (2019) evaluated secondary school science textbooks in terms of experiment and activity safety. It has

Table 2 Students' knowledge of safety symbols

\begin{tabular}{|c|c|c|c|c|c|c|c|c|c|}
\hline \multirow[t]{2}{*}{ Themes } & \multirow[t]{2}{*}{ Codes } & \multicolumn{2}{|c|}{ 6th Grade } & \multicolumn{2}{|c|}{ 7th Grade } & \multicolumn{2}{|c|}{ 8th Grade } & \multicolumn{2}{|c|}{ Total } \\
\hline & & $\mathrm{f}$ & $\%$ & $\mathrm{f}$ & $\%$ & $\mathrm{f}$ & $\%$ & $\mathrm{f}$ & $\%$ \\
\hline \multirow[t]{8}{*}{ Symbols } & Sharp and Pointed Objects & 27 & 69.2 & 52 & 96.2 & 33 & 76.7 & 112 & 82.3 \\
\hline & Heat Safety & 10 & 25.6 & 38 & 70.3 & 36 & 83.7 & 84 & 61.7 \\
\hline & Electrical Safety & 16 & 41 & 32 & 59.2 & 25 & 58.1 & 73 & 53.6 \\
\hline & Chemical Substance Warning & 27 & 69.2 & 47 & 87 & 37 & 86 & 111 & 81.6 \\
\hline & Animal Safety & - & - & 29 & 53.7 & 1 & 2.3 & 30 & 22.1 \\
\hline & Glass Equipment Warning & 5 & 12.8 & 29 & 53.7 & 14 & 32.5 & 48 & 35.2 \\
\hline & Hand Cleaning Warning & 31 & 79.4 & 36 & 66.6 & 29 & 67.4 & 96 & 70.5 \\
\hline & Lab Coat Warning & 27 & 69.2 & 45 & 83.3 & 36 & 83.7 & 108 & 79.4 \\
\hline
\end{tabular}


Table 3 Students' views on having sufficient knowledge about laboratory safety

\begin{tabular}{lllllllll} 
& \multicolumn{2}{l}{ 6th Grade } & \multicolumn{2}{l}{ 7th Grade } & \multicolumn{2}{l}{ 8th Grade } & \multicolumn{2}{l}{ Total } \\
\cline { 2 - 9 } & $\mathrm{f}$ & $\%$ & $\mathrm{f}$ & $\%$ & $\mathrm{f}$ & $\%$ & $\mathrm{f}$ & $\%$ \\
\hline Yes & 13 & 33.3 & 20 & 37.1 & 14 & 32.5 & 47 & 34.5 \\
No & 26 & 66.7 & 34 & 62.9 & 29 & 67.5 & 89 & 65.5 \\
\hline
\end{tabular}

Table 4 Student views on safe working environment

\begin{tabular}{|c|c|c|c|c|c|c|c|c|c|}
\hline \multirow[t]{2}{*}{ Themes } & \multirow[t]{2}{*}{ Codes } & \multicolumn{2}{|c|}{ 6th Grade } & \multicolumn{2}{|c|}{ 7th Grade } & \multicolumn{2}{|c|}{ 8th Grade } & \multicolumn{2}{|c|}{ Total } \\
\hline & & $\mathrm{f}$ & $\%$ & $\mathrm{f}$ & $\%$ & $\mathrm{f}$ & $\%$ & $\mathrm{f}$ & $\%$ \\
\hline \multirow{6}{*}{$\begin{array}{l}\text { Use of } \\
\text { chemicals }\end{array}$} & Storing the chemicals in a separate cabinet & 1 & 2.5 & 2 & 3.7 & - & - & 3 & 2.2 \\
\hline & $\begin{array}{l}\text { Storing flammable and volatile substances in closed } \\
\text { bottles }\end{array}$ & - & - & - & - & 1 & 2.3 & 1 & 0.7 \\
\hline & Not touching/not smelling chemicals & 10 & 25.6 & 20 & 37 & 18 & 41.8 & 48 & 35.2 \\
\hline & Not mixing different chemicals & 1 & 2.5 & 4 & 7.4 & 5 & 11.6 & 10 & 7.3 \\
\hline & Not using out-of-date materials & - & - & - & - & 1 & 2.3 & 1 & 0.7 \\
\hline & Not exposing chemicals that could cause explosions & 3 & 7.6 & - & - & 2 & 4.6 & 5 & 3.6 \\
\hline \multirow{4}{*}{$\begin{array}{l}\text { Layout of } \\
\text { the } \\
\text { laboratory } \\
\text { environment }\end{array}$} & Keeping the lab clean and tidy & 23 & 58.9 & 41 & 75.8 & 5 & 11.5 & 69 & 50.7 \\
\hline & $\begin{array}{l}\text { Checking around before leaving the laboratory (Is the } \\
\text { plug pulled out? Is the spirit extinguished? etc.) }\end{array}$ & 1 & 2.5 & 6 & 11.1 & 3 & 6.9 & 10 & 7.3 \\
\hline & Venting the lab & - & - & - & - & 2 & 4.6 & 2 & 1.4 \\
\hline & Not leaving the windows open & 2 & 5.1 & 3 & 5.5 & 1 & 2.3 & 6 & 4.4 \\
\hline \multirow{6}{*}{$\begin{array}{l}\text { Unwanted } \\
\text { student } \\
\text { behavior }\end{array}$} & Using laboratory materials without permission & 17 & 43.5 & 19 & 35.1 & 7 & 16.2 & 43 & 31.6 \\
\hline & Running in the lab & 14 & 35.8 & 6 & 11.1 & 12 & 27.9 & 32 & 23.5 \\
\hline & Joking/fighting in the lab & 5 & 12.8 & 3 & 5.5 & 1 & 2.3 & 9 & 6.6 \\
\hline & $\begin{array}{l}\text { Using laboratory materials carelessly/ damage to } \\
\text { materials }\end{array}$ & - & - & 16 & 29.6 & - & - & 16 & 11.7 \\
\hline & Eating and drinking somethings & 1 & 2.5 & - & - & 1 & 2.3 & 2 & 1.4 \\
\hline & Pouring water on the ground & - & - & 2 & 3.7 & - & - & 2 & 1.4 \\
\hline \multirow{5}{*}{$\begin{array}{l}\text { General } \\
\text { measures }\end{array}$} & Fixing cabinets to the wall & 1 & 2.5 & - & - & - & - & 1 & 0.7 \\
\hline & Keeping a first aid kit & - & - & - & - & 1 & 2.3 & 1 & 0.7 \\
\hline & Hanging signs with safety warnings & - & - & - & - & 1 & 2.3 & 1 & 0.7 \\
\hline & Staying calm in adverse situations such as fire. etc. & 2 & 5.1 & - & - & 3 & 6.9 & 5 & 3.6 \\
\hline & Not to panic in the event of an accident & - & - & - & - & 3 & 6.9 & 3 & 2.2 \\
\hline \multirow{5}{*}{$\begin{array}{l}\text { Working } \\
\text { rules }\end{array}$} & Listening to the teacher/paying attention to warnings & 11 & 28.2 & 8 & 14.8 & 6 & 13.9 & 25 & 18.3 \\
\hline & $\begin{array}{l}\text { Seeking help from the teacher with dangerous } \\
\text { experiments }\end{array}$ & - & - & - & - & 1 & 2.3 & 1 & 0.7 \\
\hline & $\begin{array}{l}\text { Using protective equipment such as gloves, lab } \\
\text { glasses, lab coat during the experiment }\end{array}$ & 4 & 10.2 & 17 & 31.4 & 31 & 72.1 & 52 & 38.2 \\
\hline & Doing experiment with security measures & 5 & 12.8 & 5 & 9.2 & 8 & 18.6 & 18 & 13.2 \\
\hline & Not watching dangerous experiments closely & 2 & 5.1 & - & - & 5 & 11.6 & 7 & 5.1 \\
\hline
\end{tabular}

been determined that the science textbooks mainly include activities requiring low-level security measures and few activities that require medium and high-level security measures. In addition, it was observed that safety symbols were used enough to take necessary precautions in the activities. It is necessary but not sufficient to include safety symbols in the science textbooks. To reduce the risk of accidents, students must recognize the safety symbols and act accordingly in laboratory studies. In this study, although the students were asked about the safety symbols in science textbooks, it was seen that the meaning of each symbol was not known enough.

\subsection{Secondary School Students' Views on Laboratory Safety}

In the second part of the questionnaire, four questions were asked to the students. First of all, the students were asked if they had enough information about laboratory safety. The frequency and percentage values of the answers are given in Table 3

According to Table 3, 34.5\% of the students think that they have sufficient knowledge about laboratory safety, while $65.5 \%$ think that they do not have sufficient knowledge. While $33.3 \%$ of 6th graders, $37.1 \%$ of 7 th graders, and $32.5 \%$ of 8 th graders think that they have sufficient knowledge, $66.7 \%$ of 6th graders, $62.9 \%$ of 7 th graders, and $67.5 \%$ of 8 th graders think that they do not have sufficient knowledge about laboratory safety. In short, most of the students do not think they have sufficient knowledge about laboratory safety.

In the second question, their views were asked about what should be considered in terms of safety during 
laboratory studies. The frequency and percentage values of student views are given in Table 4

When Table 4 is examined, it is seen that students' views about a safe working environment are grouped under five themes. Students mainly stated that chemicals should not be touched/smelled $(35.2 \%)$. In the theme of the laboratory environment's layout, it was mostly stated that the laboratory should be kept clean and tidy (50.7\%). Most of the students emphasized the wrong behaviors that threaten the safe working environment at all grade levels. In the theme of unwanted student behavior, students mostly explained that behaviors such as "using laboratory materials without permission (31.6\%)" and "running in the lab (23.5\%)" are wrong. In the theme of general measures, it is noteworthy that 7th-grade students did not give any opinion, and very few students from the 6th and 8th Grade made statements. In the theme of working rules, students mostly stated that behaviors such as "using protective equipment such as gloves, lab glasses, lab coat during the experiment $(38.2 \%) "$, "listening to the teacher/paying attention to warnings $(18.3 \%)$ ", "doing an experiment with security measures (13.2\%)" must be done. When the table is examined in general, it is noteworthy that the number of students explaining the behaviors that must/must not be done is low and that 8 th graders have more views about the safe working environment.

Most of the behaviors were expressed by a small number of students, showing that they lack knowledge on this subject. Most of the students do not know what must/must not be done during laboratory studies, and they have already expressed this view in the previous question. Okebukola et al. (2020) investigated the awareness level and implementation of the best practices of chemical safety by senior secondary school chemistry students in Nigerian. Students in rural schools were found to have a lower level of awareness of chemical safety than the students in urban schools. It was stated that this situation was due to a low level of chemistry laboratory resourcing, inadequate chemical safety training of the teachers, inadequacies in safety tools, charts, and kits, and weak enforcement of safety regulations. In some studies, it was observed that students were not given sufficient information about laboratory safety (Aydoğdu \& Pekbay, 2016) and students had deficiencies about the precautions to be taken (Ateş \&
Özarslan, 2013; Y1lmaz, 2005). However, specific rules must be followed in laboratory studies. Students must be informed about these rules and raise awareness. 'Teachers' lack of informing and raising students' awareness is an essential factor in the occurrence of problems in the laboratory (Aydoğdu \& Pekbay, 2016).

In the third question, it was asked what kind of problems may arise when safety precautions are not considered in laboratory studies. The frequency and percentage values of student views are given in Table 5 .

According to Table 5, students think that problems may arise in the laboratory environment or people working in this environment. Students mostly think that problems such as "injury/disability (63.9\%)", "explosion (36.7\%)", "fire (30.1\%)" may occur. The 6th and 8th graders mostly stated that laboratory-related problems such as "explosion (43.5\%-37.2\%)", "fire (38.4\%-46.5\%)" may occur; 7th graders mostly stated that laboratory-related problems such as "explosion (31.4\%)" and "damage to lab materials $(14.8 \%) "$ may occur. While "injury/disability (61.5\%64.8\%-65.1\%)" was mostly stated as the people-related problem at each grade level, "electric shock" was reported only by 7 th graders $(22.2 \%)$. Students may have made such inferences due to an accident they had or news they heard about it. This is in line with Ateş \& Özarslan (2013) findings that students think that injury problems may occur mostly if safety precautions are not taken into account in laboratory studies. Deniz \& Ercan-Kalkan (2013) explained that "fire, poisoning, electric shock, explosions, chemical spills, toxic smoke formation, etc." problems may occur if safety measures are not considered. Tekbiyık \& Tepe (2017) examined the laboratory accidents that occurred between the years 2001-2017 and concluded that students caused the most accidents and that the accidents mostly occurred in the form of poisoning/burning/injury. Accidents in the laboratory are mostly caused by factors such as the ignorance of teachers and students, careless and unconscious behaviors of them, and not knowing how to intervene in possible accidents (Aydoğdu \& Yardımc1, 2013; Aydoğdu \& Pekbay, 2016). This can cause problems from simple injuries to fatal accidents in laboratory studies. In this context, both teachers and students must take the necessary measures for a safe working environment.

Table 5 Problems that may arise in laboratory studies

\begin{tabular}{|c|c|c|c|c|c|c|c|c|c|}
\hline \multirow[t]{2}{*}{ Themes } & \multirow[t]{2}{*}{ Codes } & \multicolumn{2}{|c|}{ 6th Grade } & \multicolumn{2}{|c|}{ 7th Grade } & \multicolumn{2}{|c|}{ 8th Grade } & \multicolumn{2}{|c|}{ Total } \\
\hline & & $\mathrm{f}$ & $\%$ & $\mathrm{f}$ & $\%$ & $\mathrm{f}$ & $\%$ & $\mathrm{f}$ & $\%$ \\
\hline Laboratory & Fire & 15 & 38.4 & 6 & 11.1 & 20 & 46.5 & 41 & 30.1 \\
\hline \multirow[t]{2}{*}{ Related } & Explosion & 17 & 43.5 & 17 & 31.4 & 16 & 37.2 & 50 & 36.7 \\
\hline & Lab materials may be damaged & 5 & 12.8 & 8 & 14.8 & 9 & 20.9 & 22 & 16.1 \\
\hline People & Injury/disability & 24 & 61.5 & 35 & 64.8 & 28 & 65.1 & 87 & 63.9 \\
\hline Related & Electric shock & - & - & 12 & 22.2 & - & - & 12 & 8.8 \\
\hline
\end{tabular}


Table 6 Expectations regarding laboratory safety

\begin{tabular}{|c|c|c|c|c|c|c|c|c|c|}
\hline \multirow[t]{2}{*}{ Themes } & \multirow[t]{2}{*}{ Codes } & \multicolumn{2}{|c|}{ 6th Grade } & \multicolumn{2}{|c|}{ 7th Grade } & \multicolumn{2}{|c|}{ 8th Grade } & \multicolumn{2}{|c|}{ Total } \\
\hline & & $\mathrm{f}$ & $\%$ & $\mathrm{f}$ & $\%$ & $\mathrm{f}$ & $\%$ & $\mathrm{f}$ & $\%$ \\
\hline \multirow[t]{7}{*}{ Teacher } & $\begin{array}{l}\text { Putting laboratory materials in the right place (storing } \\
\text { chemicals in a different cabinet) }\end{array}$ & 2 & 5.1 & 4 & 7.4 & - & - & 6 & 4.4 \\
\hline & $\begin{array}{l}\text { Providing information about the materials to be used in } \\
\text { the experiment }\end{array}$ & 9 & 23 & 7 & 12.9 & 8 & 18.6 & 24 & 17.6 \\
\hline & Informing us about safety measures & 7 & 17.9 & 10 & 18.5 & 19 & 44.1 & 36 & 26.4 \\
\hline & Taking more precautions & 1 & 2.5 & 1 & 1.8 & 2 & 4.6 & 4 & 2.9 \\
\hline & Helping us in dangerous experiments & 2 & 5.1 & 4 & 7.4 & 1 & 2.3 & 7 & 5.1 \\
\hline & Acting exemplary by using protective equipment & 1 & 2.5 & - & - & 2 & 4.6 & 3 & 2.2 \\
\hline & $\begin{array}{l}\text { Preventing our contact with harmful substances such as } \\
\text { chemicals. etc. }\end{array}$ & - & - & 5 & 9.2 & 4 & 9.3 & 9 & 6.6 \\
\hline \multirow[t]{10}{*}{ Administrators } & Fixing the cabinets & 5 & 12.8 & 3 & 5.5 & - & - & 8 & 5.8 \\
\hline & Training on laboratory safety & 10 & 25.6 & 16 & 29.6 & 9 & 20.9 & 35 & 25.7 \\
\hline & Purchasing new and quality materials for the laboratory & 4 & 10.2 & 1 & 1.8 & 3 & 6.9 & 8 & 5.8 \\
\hline & Detecting broken/non-working materials & 1 & 2.5 & 1 & 1.8 & 10 & 23.2 & 12 & 8.8 \\
\hline & Putting warning signs on the walls/cupboards & 1 & 2.5 & 3 & 5.5 & 6 & 13.9 & 10 & 7.3 \\
\hline & Providing safety equipment such as gloves/lab glasses & 1 & 2.5 & - & - & 2 & 4.6 & 3 & 2.2 \\
\hline & Having special cabinets for chemicals & - & - & 7 & 12.9 & 1 & 2.3 & 8 & 5.8 \\
\hline & $\begin{array}{l}\text { Installing a camera in the laboratory and detecting } \\
\text { students who commit security violations }\end{array}$ & - & - & 2 & 3.7 & - & - & 2 & 1.4 \\
\hline & Doing safety drills & - & - & - & - & 2 & 4.6 & 2 & 1.4 \\
\hline & No expectation/Unrelated response & 12 & 30.7 & 16 & 29.6 & 5 & 11.6 & 33 & 24.2 \\
\hline
\end{tabular}

In the fourth question, the students were asked about their expectations from science teacher and school administrators regarding laboratory safety. The frequency and percentage values of student opinions are given in Table 6

According to Table 6, students expect science teachers and school administrators to take some laboratory safety precautions. At all grade levels, the science teacher is mainly expected to inform students about safety precautions (17.9\%-18.5\%-44.1\%) and introduce the materials used in the experiment (23\%-12.9\%-18.6\%). In addition, students expect most from the school administration to provide training on laboratory safety. It is also noteworthy that many students made irrelevant explanations and stated that they had no expectations from the science teacher $(25.6 \%$ $42.5 \%-23.2 \%$ ) or school administrators $(30.7 \%-29.6 \%$ $11.6 \%)$. Although other safety measures that are expected to be taken by the science teacher or the school administrators are also crucial, they were mentioned by very few students. These findings are in line with Ateş \& Özarslan (2013) findings that the students stated that they must be educated about laboratory safety and that various techniques (such as presentation, film, animation) must be used in this training. The laboratories must always be kept ready for a safe education environment, and students must be reminded of safety rules frequently. Stepenuck (2002) prepared a report describing the dangers of chemical materials and explained that the safety information specified in the report must be taught to students. Mogopodi, Paphane, \& Petros (2015) researched the chemical management practices and safety in junior secondary school laboratories in Gaborone. It was seen that there is a lack of knowledge and awareness on sound chemical management, and there are no measures in place for disposal of out-of-date stock or expired chemicals. In addition, chemical containers were either not labeled or had fading labels, and incompatible chemicals were stored together, increasing the risks of chemical accidents. Ezrailson (2013) stated that science teachers and school administrators have responsibilities such as checking whether there is safety equipment in the laboratory and taking necessary precautions. Some studies determined that safety equipment in school laboratories was insufficient (Demir, 2016; Emendu, 2007; Nwele, 2013). According to Ritch \& Rank (2001), science laboratory safety at all levels must be taken seriously. Accidents are commonly reported in science laboratories worldwide, which underlined the need for awareness and adequate information on the importance of prioritizing safety in science laboratories

\section{CONCLUSION}

As a result of the study, it was seen that although secondary school students have some general information 
about laboratory safety, they have deficiencies in terms of most of the information. It was determined that students do not know most of the behaviors that must/must not be made in the laboratory, and they are not aware of some of the safety symbols in the science textbooks. Besides, most of the students stated that they don't feel competent about laboratory safety and need training on this subject.

The following suggestions can be made in line with the results of the study:

- As a result of the study, it was observed that although secondary school students had general knowledge about laboratory safety, they did not have detailed information. Therefore, students should be informed about some issues such as safety symbols, the purpose of using laboratory materials, what to do before/during/after the experiment, and how to behave in possible accidents.

- Although the students were asked about the safety symbols found in the textbooks, it was determined that they did not have any idea about some safety symbols. This shows that the presence of safety symbols in textbooks alone is not enough. Teachers should show the necessary sensitivity in conveying this information to students.

- The students explained the behaviors that should and should not be done in a safe working environment. Long-term laboratory observations can be made to compare whether students' views and actions coincide.

- Students expect both science teachers and school administrators to provide information about laboratory safety. They expressed that they felt inadequate in this area. Interviews can be done with school administrators and science teachers about this issue. "Have students been trained on this subject before? If so, by whom and how often?" Answers to such questions can be sought. Besides, the laboratory safety knowledge test can be used to determine which subject students need information.

- To properly educate the students about laboratory safety, he/she must first have the correct and sufficient knowledge. Therefore, teachers' knowledge and views about laboratory safety can be investigated.

- Similar studies can be conducted on different samples in different schools. Increasing the number of researches will provide more information on the subject and reveal whether there is consistency among the results.A quantitative data collection tool was used in this study. By using qualitative data collection tools, research can be done, and in-depth information can be accessed. For example, "Are students taking enough personal responsibility or do they see it as their teacher's job? What are the responsibilities of students and teachers regarding laboratory safety?". Answers to such questions can be sought by conducting interviews with students and teachers

\section{REFERENCES}

Alaimo, P. J., Langenhan, J. M., Tanner, M. J., \& Ferrenberg, S. M. (2010). Safety teams: An approach to engage students in laboratory safety. Journal of Chemical Education, 87(8), 856-861.

Ali, N. L., Ta, G. C., Zakaria, S. Z. S., Halim, S. A., Mokhtar, M., Ern, L. K., \& Alam, L. (2018). Assessing awareness on laboratory safety: A case study in Pahang, Malaysia. Jurnal Pendidikan Malaysia, 43(2), 73-80.

Anilan, B. (2010). The recognition level of the students of science education about the hazard symbols of chemicals (Case of ESOGU, Eskisehir). Procedia Social and Behavioral Sciences, 2(2), 40924097.

Artdej, R. (2012). Investigating undergraduate students' scientific understanding of laboratory safety. Procedia Social and Behavioral Sciences, 46, 5058-5062.

Ateș, İ., \& Özarslan, M. (2013). Üstün zekalı ve yetenekli öğrencilerin fen bilimleri laboratuvar çalışmalarındaki güvenlik önlemleri ile ilgili görüşleri [The opinions of gifted and talented students about security measures in science laboratory studies]. Journal of Educational Science, 2(3), 42-49.

Aydın, S., Diken, E. H., Yel, M., \& Yılmaz, M. (2011). Fen ve teknoloji ile biyoloji öğretmen adaylarının laboratuvar güvenliği hakkındaki bilgi düzeylerinin belirlenmesi [Determining the science and technology and biology teacher candidates' knowledge levels about laboratory safety]. Journal of Gazi Education Faculty, 31(2), 583-604.

Aydoğdu, C., \& Yardımc1, E. (2013). İlköğretim fen laboratuvarlarında meydana gelen kazalar ve öğretmenlerin geliştirebilecekleri davranış tarzlar1 [Accidents that occur in primary education science laboratories and behaviors that teachers can develop]. Hacettepe University Journal of Education Faculty, 44, 52-60.

Aydoğdu, C., \& Pekbay, C. (2016). Sınıf öğretmen adaylarının laboratuvarlarda yaşanan kazaların nedenlerine yönelik görüşleri [The opinions of the classroom teacher candidates about the causes of the accidents in the laboratories]. Journal of Education Science and Technology Research, 1(2), 103-112.

Aydoğdu, C. (2018). Historical development of laboratory in the elementary school science program in Turkey. M. Shelley \& S. A. Kiray (Eds.), Education Research Highlights in Mathematics, Science and Technology (pp. 141-174). Iowa: ISRES Publishing.

Bayraktar, S.., Erten, S., \& Aydoğdu, C. (2006). Fen ve teknoloji ögretiminde laboratuvarın önemi ve deneyler [The importance of the laboratory and experiments in science and technology teaching]. M. Bahar (Editor), Science and technology teaching (pp. 219248). Ankara: Pegem A Publishing.

Böyük, U., Demir, S., \& Erol, M. (2010). Fen ve teknoloji dersi öğretmenlerinin laboratuvar çalş̧malarına yönelik yeterlik görüşlerinin farklı değişkenlere göre incelenmesi [Examination of science and technology lesson teachers' efficacy opinions on laboratory studies according to different variables]. TUBAV Journal of Science, 3(4), 342-349.

Canel, M. (2002). Laboratuvar güvenlïgi [Laboratory safety]. Ankara University, Faculty of Science, Revolving fund business publications, No:26, Ankara.

Çepni, S. (2012). Araștırma ve proje çallsmalarna Giris (6. Basker) [Introduction to research and project work (6th Edition)]. Trabzon: Celepler Publishing.

Demir, E. (2016). Fen laboratuvarlarının fiziki şartlarının ve fen bilimleri öğretmenlerinin laboratuvar güvenliği konusundaki bilgi düzeylerinin araştırilması [Investigation of the physical conditions of science laboratories and science teachers' knowledge level about laboratory safety]. Master Thesis, Gazi University, Ankara.

Deniz, V., \& Ercan-Kalkan, M. (2013). Laboratuvar kazalar1 [Laboratory accidents].https://www.isgturkiye.com/konu/laboratuvarkazalari.3551/

Derman, M., \& Çakmak, M. (2016). Biyoloji öğrencilerinin laboratuvar güvenliği konusundaki görüşlerinin incelenmesi [Examination of 
biology students' opinions on laboratory safety]. Bartm University Journal of Education Faculty, 5(1), 178-187.

Emendu, N. B. (2007). The status of safety precaution and adequacy of equipment in chemistry laboratories in senior secondary schools in Anambra State. In The Nigerian Academic Forum: A Multidisciplinary Journal, 12, 84-89.

Ezrailson, C. M. (2013). Danger in the school science lab: Are students at risk? Proceedings of the South Dakota Academy of Science, 92, 149-164.

Gerlovich, J., Parsa, R., \& Jordan, L. (2004). The 2003 status of science safety in Tennessee secondary schools. Journal of the Tennessee Academy of Science, 79(4), 83-90.

Gökmen, A., \& Atmaca, S. (2019). Öğretmen adavlarının laboratuvar güvenlik işaretleri konusundaki farkındalıkları [Pre-service teachers' awareness of laboratory safety signs]. Journal of Education and Social Research, 6(2), 426-442.

Gudyanga, R. (2020). Probing physical sciences teachers' chemical laboratory safety awareness in some South African high schools. African Journal of Research in Mathematics, Science and Technology Education, 24(3), 423-434.Hackling, M., Goodrum, D., \& Rennie, L. (2001). The state of science in Australian secondary schools. Australian Sciences Teachers' Journal, 47(4), 12-17.

Hamurcu, H. (1998). Fen derslerinde güvenlik [Safety in science classes]. Hacettepe University Journal of Education Faculty, 14(14), 29-32.

Hasenekoğlu, İ. (2003). Laboratuvar güvenliği (2-3) [Laboratory safety (23)]. Erzurum: Kazım Karabekir Education Faculty Publications.

Hill, R. H., \& Finster, D. C. (2010). Laboratory safety for chemistry students. New Jersey: John Wiley \& Sons Publishing.

Hodson, D. (1990). A critical look at practical work in school science. School Science Review, 70, 33- 40

Hofstein, A., \& Lunetta, V.N. (2004). The Laboratory in science education: Foundations for the twenty-first century. Science Education, 88, 28-54.

Hsieh, H. F., \& Shannon, S. E. (2005). Three approaches to qualitative content analysis. Qualitative Health Research, 15(9), 1277-1288.

Karasar, N. (2004). Bilimsel araştırma yöntemi (13. basker) [Scientific research method (13th edition)7. Ankara: Nobel Publishing.

Kerimak-Öner, M. N. (2020). Kimya eğitiminde laboratuvar güvenliği kültürünün yerleștirilmesi [Placement of laboratory safety culture in chemistry education]. ISG Academic, 2(1), 15-25.

Kırbaşlar, F.G, Özsoy-Güneş, Z., \& Derelioğlu, Y. (2010). Fen bilgisi öğretmen adaylarının laboratuvar güvenliği konusuna yönelik düşünce ve bilgi düzeylerinin araştırılması [Investigation of preservice science teachers' level of thought and knowledge on laboratory safety.]. Journal of Gazi Education Faculty, 30(3), 801-818.

Miles, M. B., \& Huberman, A. M. (1994). Qualitative data analysis: An expanded sourcebook. Thousand Oaks, CA: Sage Publications.

Miles, M., Huberman, M., \& Saldana, J. (2014). Qualitative data analysis: A methods sourcebook. European journal of science education. Los Angeles: Sage Puplication, Thousand Oaks.

Mogopodi, D., Paphane, B., \& Petros, S. (2015). Assessment of chemical management practices and safety in junior secondary school laboratories in Gaborone. Journal of Chemical Health \& Safety, 22(5), $17-27$.

Muhammad, R. (2017). Assessing the laboratory safety and security skills among science, technology and mathematics (STM) teachers in Sokoto State, Nigeria. American Journal of Education and Learning, 1(2), 62-68.

Nakiboğlu C., \& Sarıkaya, Ş. (1999). Orta öğretim kurumlarında kimya derslerinde görevli öğretmenlerin laboratuvardan yararlanma durumlarının değerlendirilmesi [Evaluation of the use of laboratory by teachers working in chemistry lessons in secondary education institutions]. Journal of Buca Education Faculty, 11, 395- 405.

Nwele, C. N. (2013). Extent of availability of safety instruments/equipment in science laboratories in secondary schools in Ebonyi State of Nigeria. Academic Journal of Interdisciplinary Studies, 2(10), 131-136.

Okebukola, P. A., Oladejo, A., Onowugbeda, F., Awaah, F., Ademola, I., Odekeye, T., \& Ajayi, O. A. (2020). Investigating chemical safety awareness and practices in Nigerian schools. Journal of Chemical Education, 98(1), 105-112.

Ritch, D., \& Rank, J. (2001). Laboratory safety in the biology lab. Bioscene, 27(3), 17-22.

Singer, S. R., Hilton, M. L., \& Schweingruber, H. A. (2006). America's lab report: Investigations in high school science. Committee on bigh school science laboratories: Role and vision. Washington D.C.: National Research Council, National Academies Press.

Stepenuck, S. (2002). Material safety data sheets. NEACT Journal, 21(1), 28-32.

Tekbıyık, A., \& Tepe, M. (2017). Türkiye'de 2001-2017 yılları arasında yaşanan laboratuvar ve deney kazalarının değerlendirilmesi [Evaluation of laboratory experiments and accidents that occurred between the years of 2001-2017 in Turkey]. International Journal of Innovative Approaches in Education, 1(1), 11-20.

Tepe, M., \& Tekbıyık (2019). Ortaokul fen bilimleri ders kitaplarının deney ve etkinlik güvenliği bakımından değerlendirilmesi [Evaluation of secondary school science textbooks in terms of experiment and effectiveness safety]. Journal of National Education, 48(1), 223-240.

Topsakal, S. (2006). Ë̆itim fakülteleri sinnf ve fen bilgisi bölümü ögrencileri ile sima ve fen bilgisi ögretmenleri için ilkö̈gretim 6. 7. ve 8. smaflar fen ve teknoloji ögretimi Primary 6th, 7th and 8th grades science and technology education for students of education faculties, classroom and science departments, and classroom and science teachers 7 . Ankara: Nobel Publishing.

Uluçınar, Ş., Cansaran, A., \& Karaca, A. (2004). Fen bilimleri laboratuvar uygulamalarının değerlendirilmesi [Evaluation of science laboratory applications]. Turkish Journal of Educational Sciences, 2(4), 465- 475.

West, S. S., Westerlund, J. F., Stephenson, A. L., Nelson, N. C., \& Nyland, C. K. (2003). Safety in science classrooms: what research and best practice say. In The Educational Forum, 67(2), 174-183.

Yazıc1, E.K., \& Özmen, H. (2015). Fen ve teknoloji öğretim programinda yer alan deney ve etkinliklerin uygulanabilirliğine ilişkin ögrretmen görüşleri [Teachers' views on the applicability of the experiments and activities in the science and technology curriculum]. Amasya University Journal of Education Faculty, 4(1), 92117.

Yıldırım, A., \& Şimșek, H. (2006). Sosyal bilimlerde nitel araștırma yöntemleri Qualitative research methods in the social sciences]. Ankara: Seçkin Publishing.

Yılmaz, A. (2005). Lise 1 kimya ders kitabındaki bazı deneylerde kullanılan kimyasalların tehlikeli özelliklerine yönelik öğrencilerin bilgi düzeyleri ve öneriler [Students' knowledge levels and recommendations regarding the dangerous properties of chemicals used in some experiments in the high school 1 chemistry textbook]. Hacettepe University Journal of Education Faculty, 28, 226235. 